\title{
REACTIVITY OF CERTAIN BIOLOGICALLY IMPORTANT AZOLES AND MORPHOLINE TOWARDS Ni(II) AND Cu(II) COMPLEXES OF O-HYDROXYACETOPHENONEETHANOLIMINE AND N-SALICYLIDENE DERIVATIVES
}

Aref A. M. Aly ${ }^{1}$, Ahmed H. Osman ${ }^{1}$, Mohamed Abd El-Mottaleb ${ }^{2}$ and Gamal A.H. Gouda ${ }^{2}$

${ }^{1}$ Department of Chemistry, Faculty of Science, Assiut University, Assiut, Egypt

${ }^{2}$ Department of Chemistry, Faculty of Science, Al-Azhar University (Assiut), Egypt

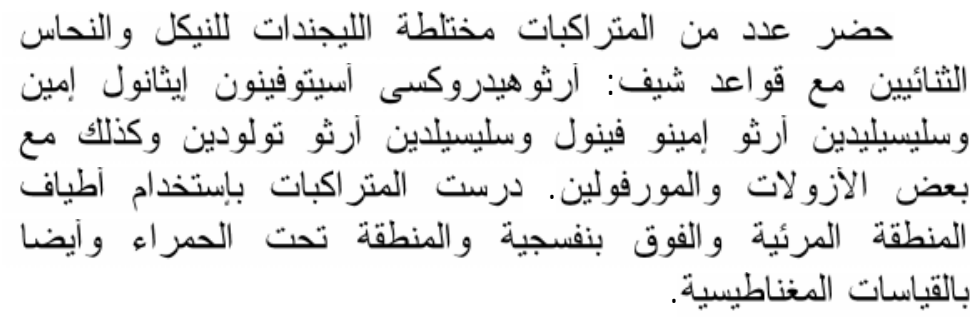

A number of mixed ligand complexes of $\mathrm{Ni}(\mathrm{II})$ and $\mathrm{Cu}(\mathrm{II})$ containing the Schiff bases: o-hydroxyacetophenoneethanolimine (OHAE), N-salicylidene-o-iminophenol (SOP) and N-salicylideneo-toluidine (SOT) as well as morpholine or the azoles: 2aminothiazole, benzothiazole and 2-methylbenzothiazole has been prepared and characterized. The IR, UV-VIS spectra and magnetic moment measurements of the complexes were discussed.

\section{INTRODUCTION}

Azomethine derivatives and their metal complexes perform an important role in biological systems. ${ }^{1 \& 2}$ Many Schiff bases exhibit antiviral and antimicrobial activity ${ }^{3}$ and are used as mimetic systems for enzyme models ${ }^{4}$ besides their

Received in 9/2/2006 \& Accepted in 2/5/2006 
importance in pharmaceutical technology. ${ }^{5}$

Furthermore, the increasing interest in the chemistry of five membered heterocyclic molecules and their metal complexes is due to their biological and pharmaceutical importance. $^{6 \& 7}$ It was recently reported that complexes of 2aminothiazole exhibit some significant in vivo antitumor activitry against P388 leukemia. ${ }^{8 \& 9}$ In view of this importance of Schiff bases and thiazoles and in view of our interest in the coordination chemistry of these Lewis bases, ${ }^{10-12}$ the present paper deals with the preparation and characterization of ternary complexes of $\mathrm{Ni}(\mathrm{II})$ and $\mathrm{Cu}(\mathrm{II})$ comprising certain Schiff bases and thiazoles or morpholine.
EXPERIMENTAL

All solvents and reagents used in this work were of analytical grade. The ligands used in this work were prepared according to reported literature procedures. ${ }^{13-15}$ Their names, notations and structures are given in Table 1 . The following binary complexes were prepared as described in the literature: ${ }^{13-16}$ aqua(ohydroxyacetophenoneethanoliminato) copper(II) (decomp. point $135^{\circ}$, light blue), aqua(N-salicylidene-o-iminophenolato)nickel(II) (decomp. point $190^{\circ}$, beige), aqua( $\mathrm{N}$-alicylidene-oiminophenolato)copper(II) (decomp. point $210^{\circ}$, green) and bis( $\mathrm{N}$ salicylidene-o-toluidine)copper(II) (decomp. point $297^{\circ}$, yellowish brown). The mixed ligand complexes were prepared as follows:

Table 1: Names, notations and structures of the ligands under investigation.

\begin{tabular}{||l|c|c|c|}
\hline \multicolumn{1}{|c|}{ Names } & Notation & Structure \\
\hline $\begin{array}{l}\text { o-Hydroxyacetophenone- } \\
\text { ethanolimine }\end{array}$ & (OHAE $)$ & \\
\hline N-Salicylidene-o-iminophenol & $(\mathrm{SOP})$ & \\
\hline N-Salicylidene-o-toluidine & $(\mathrm{SOT})$ & \\
\hline
\end{tabular}


(i) Preparation of (o-hydroxyacetophenoneethanoliminato)(2aminothiazole)copper(II), [Cu(OHAE) (2-Atz)], (ohydroxyacetophenoneethanoliminato)(benzothiazole)copper(I I), [Cu(OHAE) (Btz)], (ohydroxyacetophenoneethanoliminato)(3-methyl-2-selenoxothazothiazole)copper (II), [Cu(OHAE)(3-Msbbtz)] and (ohydroxyacetophenoneethanoliminato)(thiabendazole)copper (II)monohydrate, [Cu(OHAE) (Tbdz)]. $\mathrm{H}_{2} \mathrm{O}$

A methanolic solution $(50 \mathrm{ml})$ of $\left[\mathrm{Cu}(\mathrm{OHAE})\left(\mathrm{H}_{2} \mathrm{O}\right)\right](0.012 \mathrm{~mol})$ was mixed with a methanolic solution (20 $\mathrm{ml}$ ) of 2-aminothiazole (2-Atz), benzothiaozle (Btz), 3-methyl-2selenoxobenzothiazole (3-Msbtz) or thiabendazole (Tbdz) (0.012 mol) with continuous stirring for about 15 minutes. The mixture was then heated under reflux for 3-4 h. The solution was filtered and allowed to cool, whereby brown or green precipitates were obtained. The collected solid chelates were washed with methanol and dried in air.

(ii) Preparation of $\mathbf{( N - s a l i c y l i d e n e - ~}$ o-iminophenolato)(2-aminothiazole)nickel(II), [Ni(SOP)(2Atz)], (N-salicylidene-o-iminophenolato)(benzothiazole)nickel (II), [Ni(SOP)(Btz)], (N-salicylidene-o-iminophenolato)(2methylbenzothiazole)nickel(II), [Ni(SOP)(2-Mbtz)] and (Nsalicylidene-o-iminophenolato)(morpholine)nickel(II), [Ni(SOP)(Morph)]

A methanolic solution $(30 \mathrm{ml})$ of $\left[\mathrm{Ni}(\mathrm{SOP})\left(\mathrm{H}_{2} \mathrm{O}\right)\right] \quad(0.001 \mathrm{~mol})$ was mixed with a methanolic solution (15 ml) of 2-aminothizole (2-Atz), benzothiazole (Btz), 2-methylbenzothiazole (2-Mbtz) or morpholine (Morph) $(0.001 \mathrm{~mol})$, and then the mixtures were heated under reflux for 4-5 h. Upon reduction of the mixture volume and cooling, coloured solids of the ternary complexes separated out, which were filtered and dried in air.

(iii) Preparation of ( $\mathrm{N}$-salicylideneo-iminophenolato)(benzothiazole)copper(II), [Cu(SOP)(Btz)]

A methanolic solution $(20 \mathrm{ml})$ of $\left[\mathrm{Cu}(\mathrm{SOP})\left(\mathrm{H}_{2} \mathrm{O}\right)\right] \quad(0.001 \mathrm{~mol})$ was mixed with a methanolic solution (20 $\mathrm{ml})$ of benzothiazole (Btz) $(0.001$ mol) and the mixture was heated under reflux for 4-5 $\mathrm{h}$. The green product was collected, washed with methanol and air dried.

(iv) Preparation of bis( $\mathrm{N}$-salicy-

lidene-o-toludine)bis-

(morpholine) copper(II), $\left[\mathrm{Cu}(\mathrm{SOT})_{2}(\mathrm{Morph})_{2}\right]$

An ethanolic solution $(50 \mathrm{ml})$ of $\left[\mathrm{Cu}(\mathrm{SOT})_{2}\right] \quad(0.001 \mathrm{~mol})$ and an ethanolic solution $(20 \mathrm{ml})$ of morpholine (Morph) $(0.002 \mathrm{~mol})$ were mixed in a 1:2 (compelx : ligand) ratio. The mixture was refluxed on a water bath $\left(70^{\circ}\right)$ for about $3 \mathrm{~h}$. The solution was filtered and allowed to cool. A pink precipitate was separated, washed with ethanol and finally dried in air.

\section{Physical measurements}

The carbon, hydrogen, nitrogen and sulfur contents of the solid 
compounds were determined by Elementar Analysensystem GmbH Vario EL. The infrared spectra of all compounds were recorded on a 470 Shimadzu infrared spectrophotometer (4000-400 $\mathrm{cm}^{-1}$ ) using $\mathrm{KBr}$ disks. The electronic absorption spectral measurements in the ultraviolet and visible regions were carried out as nujol mull on a UV-2102 PC Shimadzu spectrophotometer, using 1 $\mathrm{cm}$ matched quartz cell in the wavelength range $200-900 \mathrm{~nm}$. The $\mathrm{X}$-ray data were collected at room temperature $\left(25^{\circ}\right)$ on a Philips 1710 diffractometer. The patterns were run with $\mathrm{Cu}$ target $(\lambda=1.5418 \AA)$ in the range of $2 \theta=10^{\circ}-70^{\circ}$ with a scanning speed of $6 \% \mathrm{~min}$. Magnetic susceptibilities of the compounds were measured at room temperature using a magnetic susceptibility balance of the type MSB-Auto. Molar susceptibilities were corrected for diamagnetism of the component atoms by the use of Pascal's constants. The calibrant used was $\mathrm{Hg}\left[\mathrm{Co}(\mathrm{SCN})_{4}\right]$.

\section{RESULTS AND DISCUSSION}

Binary complexes of $\mathrm{Ni}(\mathrm{II})$ and $\mathrm{Cu}$ (II) derived from o-hydroxyacetophenoneethanolimine, $\mathrm{N}$-salicylideneo-iminophenol or N-salicylidene-otoluidine react readily with 2-aminothiazole (2-Atz), benzothiazole (Btz), 2-methylbenzothiazol (2-Mbtz), 3methyl-2-selenoxobenzothizole (3Msbtz), thiabendazole (Tbdz) and morpholine (Morph) to form the corresponding ternary complexes. The reactions proceed according to the following equations:

$$
\begin{aligned}
{\left[\mathrm{Cu}(\mathrm{OHAE})\left(\mathrm{H}_{2} \mathrm{O}\right)\right]+\mathrm{L} } & \rightarrow \\
{[\mathrm{Cu}(\mathrm{OHAE})(\mathrm{L})] } & +\mathrm{H}_{2} \mathrm{O}
\end{aligned}
$$

where $\mathrm{L}=(2-\mathrm{Atz}),($ Btz),$(3-\mathrm{Msbtz})$ or (Tbdz)

$$
\begin{aligned}
& {\left[\mathrm{Ni}(\mathrm{SOP})\left(\mathrm{H}_{2} \mathrm{O}\right)\right]+\mathrm{L} \rightarrow} \\
& {[\mathrm{Ni}(\mathrm{SOP})(\mathrm{L})]+\mathrm{H}_{2} \mathrm{O}}
\end{aligned}
$$

where $\mathrm{L}=(2-\mathrm{Atz}),(\mathrm{Btz}),(2-\mathrm{Mbtz})$ or (Morph)

$$
\begin{gathered}
{\left[\mathrm{Cu}(\mathrm{SOP})\left(\mathrm{H}_{2} \mathrm{O}\right)\right]+\mathrm{Btz} \rightarrow} \\
{[\mathrm{Cu}(\mathrm{SOP})(\mathrm{Btz})]+\mathrm{H}_{2} \mathrm{O}} \\
{\left[\mathrm{Cu}(\mathrm{SOT})_{2}\right]+2 \mathrm{Morph} \rightarrow} \\
{\left[\mathrm{Cu}(\mathrm{SOT})_{2}(\mathrm{Morph})_{2}\right]}
\end{gathered}
$$

The resulting metal complexes can be divided into two categories according to their stoichiometric ratios, namely $1: 1$ in the ternary metal complexes [Cu(OHAE)(2-Atz)], $[\mathrm{Cu}(\mathrm{OHAE})(\mathrm{Btz})], \quad[\mathrm{Cu}(\mathrm{OHAE})(3-$ Msbtz)], [Cu(OHAE)(Tbdz)]. $\mathrm{H}_{2} \mathrm{O}$, [Ni(SOP)(2-Atz)], [Ni(SOP)(Btz)], [Ni(SOP)(2-Mbtz)], [Ni(SOP)(Morph)] and $[\mathrm{Cu}(\mathrm{SOP})(\mathrm{Bt})]$ and 1:2 metal complex to ligand in $\left[\mathrm{Cu}(\mathrm{SOT})_{2}(\mathrm{Morph})_{2}\right]$. The complexes are partially soluble in DMF, but sparingly soluble in alcohol, acetone and ether. Elemental analysis, colour and decomposition points of the ternary complexes are tabulated in Table 2 . 
Table 2: Colour, elemental analysis and decomposition points of the mixed ligand complexes.

\begin{tabular}{|c|c|c|c|c|c|c|}
\hline Compound & Colour & $\begin{array}{c}\mathrm{C} \% \\
\text { (calc.) }\end{array}$ & $\begin{array}{c}\mathrm{H} \% \\
\text { (calc.) }\end{array}$ & $\begin{array}{c}\mathrm{N} \% \\
\text { (calc.) }\end{array}$ & $\begin{array}{c}\mathrm{S} \% \\
\text { (calc.) }\end{array}$ & $\begin{array}{c}\text { Decomp } \\
\mathrm{mp} /{ }^{\circ} \mathrm{C}\end{array}$ \\
\hline $\mathrm{Cu}((\mathrm{OHAE})(2-\mathrm{Atz})]$ & Brown & $\begin{array}{c}46.48 \\
(45.80) \\
\end{array}$ & $\begin{array}{c}5.26 \\
(4.43) \\
\end{array}$ & $\begin{array}{c}13.38 \\
(12.32) \\
\end{array}$ & $\begin{array}{l}10.00 \\
(9.40) \\
\end{array}$ & 215 \\
\hline$[\mathrm{Cu}(\mathrm{OHAE})(\mathrm{Btz})]$ & Green & $\begin{array}{c}55.57 \\
(54.31)\end{array}$ & $\begin{array}{c}4.31 \\
(4.28)\end{array}$ & $\begin{array}{c}8.14 \\
(7.45)\end{array}$ & $\begin{array}{c}8.92 \\
(8.52)\end{array}$ & 216 \\
\hline$[\mathrm{Cu}(\mathrm{OHAE})(3-\mathrm{Msbtz})]$ & $\begin{array}{l}\text { Yellow- } \\
\text { ish green }\end{array}$ & $\begin{array}{c}47.00 \\
(46.10)\end{array}$ & $\begin{array}{c}4.51 \\
(3.86)\end{array}$ & $\begin{array}{c}6.43 \\
(5.97)\end{array}$ & $\begin{array}{c}7.51 \\
(6.83)\end{array}$ & 219 \\
\hline$[\mathrm{Cu}(\mathrm{OHAE})(\mathrm{Tbdz})] \cdot \mathrm{H}_{2} \mathrm{O}$ & $\begin{array}{l}\text { Light } \\
\text { green }\end{array}$ & $\begin{array}{c}53.00 \\
(52.22)\end{array}$ & $\begin{array}{c}4.71 \\
(4.38)\end{array}$ & $\begin{array}{c}13.00 \\
(11.18)\end{array}$ & $\begin{array}{c}7.50 \\
(6.97)\end{array}$ & 224 \\
\hline$[\mathrm{Ni}(\mathrm{SOP})(2-\mathrm{Atz})]$ & Brown & $\begin{array}{c}52.70 \\
(51.92)\end{array}$ & $\begin{array}{c}4.05 \\
(3.54)\end{array}$ & $\begin{array}{c}11.76 \\
(11.35)\end{array}$ & $\begin{array}{c}9.02 \\
(8.66)\end{array}$ & $>300$ \\
\hline$[\mathrm{Ni}(\mathrm{SOP})(\mathrm{Btz}]$ & Yellow & $\begin{array}{c}60.00 \\
(59.29)\end{array}$ & $\begin{array}{c}3.53 \\
(3.48)\end{array}$ & $\begin{array}{c}7.50 \\
(6.94)\end{array}$ & $\begin{array}{c}8.61 \\
(7.91)\end{array}$ & $>300$ \\
\hline $\mathrm{Ni}(\mathrm{SOP})(2-\mathrm{Mbtz})]$ & $\begin{array}{c}\text { Pale } \\
\text { yellow }\end{array}$ & $\begin{array}{c}61.01 \\
(60.17)\end{array}$ & $\begin{array}{c}4.04 \\
(3.84)\end{array}$ & $\begin{array}{c}7.20 \\
(6.68)\end{array}$ & $\begin{array}{c}8.10 \\
(7.63)\end{array}$ & $>300$ \\
\hline [Ni(SOP)(Morph)] & $\begin{array}{l}\text { Deep } \\
\text { brown }\end{array}$ & $\begin{array}{c}58.08 \\
(57.17) \\
\end{array}$ & $\begin{array}{c}5.23 \\
(5.07) \\
\end{array}$ & $\begin{array}{c}8.14 \\
(7.87) \\
\end{array}$ & $\begin{array}{l}- \\
- \\
\end{array}$ & $>300$ \\
\hline$[\mathrm{Cu}(\mathrm{SOP})(\mathrm{Btz})]$ & Green & $\begin{array}{c}59.23 \\
(58.59)\end{array}$ & $\begin{array}{c}3.56 \\
(3.44)\end{array}$ & $\begin{array}{c}7.38 \\
(6.83)\end{array}$ & $\begin{array}{c}8.50 \\
(7.82)\end{array}$ & $>300$ \\
\hline$\left[\mathrm{Cu}(\mathrm{SOT})_{2}(\mathrm{Morph})_{2}\right]$ & Pink & $\begin{array}{c}67.05 \\
(65.65)\end{array}$ & $\begin{array}{c}5.03 \\
(6.43)\end{array}$ & $\begin{array}{c}9.47 \\
(8.51)\end{array}$ & $\begin{array}{l}- \\
-\end{array}$ & 159 \\
\hline
\end{tabular}

\section{IR spectra}

The most important infrared spectral bands that provide the coordination sites in the formed ternary complexes are given in Table 3. The spectra of the ternary complexes display a band associated with a shoulder in the region 1590$1650 \mathrm{~cm}^{-1}$ that can be attributed to $v(\mathrm{C}=\mathrm{N})$ of the azomethine group and $v(\mathrm{C}=\mathrm{N})$ of the 2-aminothiazole and benzothiazole. The $v\left(\mathrm{NH}_{2}\right)$ of 2aminothiazole and $v(\mathrm{NH})$ of morpholine are observed in the range of 3190-3370 $\mathrm{cm}^{-1}$. A band appearing in the range $1200-1300 \mathrm{~cm}^{-1}$ is attributed to $v(\mathrm{C}-\mathrm{O})$ phenolic. The thiazole ligands exhibit in general
$v(\mathrm{C}-\mathrm{S})$ as a sharp band in the range $650-790 \mathrm{~cm}^{-1}$. Comparison of the spectra of the ternary complexes with those of the binary complexes was made. The bands associated with $v(\mathrm{C}=\mathrm{N})$ and $v(\mathrm{C}-\mathrm{O})$ phenolic of the binary complexes are observed in the range $1600-1620$ and $1300-1320$ $\mathrm{cm}^{-1}$, respectively. No significant shifts in the positoin of these two bands in the ternary complexes could be traced. Metal-nitrogen and metaloxygen bonding display their absorptions at 460-470 and 480-490 $\mathrm{cm}^{-1}$, respectively. ${ }^{17-20}$ This is a further evidence for coordination of the metal ions through oxygen and nitrogen atoms of the ligands. 
Table 3: IR spectral data of the complexes $\left(\mathrm{cm}^{-1}\right)$.

\begin{tabular}{||l|c|c|c|c|c|c||}
\hline \multicolumn{1}{|c|}{ Compound } & $v(\mathrm{C}=\mathrm{N})$ & $v(\mathrm{~N}-\mathrm{H})$ & $v(\mathrm{C}-\mathrm{O})$ & $v(\mathrm{C}-\mathrm{S})$ & $v(\mathrm{M}-\mathrm{O})$ & $v(\mathrm{M}-\mathrm{N})$ \\
\hline $\mathrm{Cu}((\mathrm{OHAE})(2-\mathrm{Atz})]$ & $\begin{array}{c}1660 \mathrm{~s} \\
1640 \mathrm{sh}\end{array}$ & 3290 & $1200 \mathrm{~s}$ & 790 & 490 & 470 \\
& $\begin{array}{c}1610 \mathrm{~s} \\
1620 \mathrm{sh}\end{array}$ & - & 1220 & 750 & 490 & 460 \\
\hline$[\mathrm{Cu}(\mathrm{OHAE})(\mathrm{Btz})]$ & $1600 \mathrm{~s}$ & - & 1280 & 740 & 495 & 470 \\
\hline$[\mathrm{Cu}(\mathrm{OHAE})(3-\mathrm{Msbtz})]$ & $\begin{array}{l}1595 \mathrm{~s} \\
1640 \mathrm{sh}\end{array}$ & 3300 & 1290 & 743 & 480 & 460 \\
\hline$[\mathrm{Cu}(\mathrm{OHAE})(\mathrm{Tbdz})] \cdot \mathrm{H}_{2} \mathrm{O}$ & $\begin{array}{c}1620 \mathrm{~s} \\
1650 \mathrm{sh}\end{array}$ & 3370 & 1300 & 660 & 490 & 470 \\
\hline$[\mathrm{Ni}(\mathrm{SOP})(2-\mathrm{Atz})]$ & $\begin{array}{c}1620 \mathrm{~s} \\
1655 \mathrm{sh}\end{array}$ & - & 1290 & 655 & 485 & 475 \\
\hline$[\mathrm{Ni}(\mathrm{SOP})(\mathrm{Btz}]$ & $\begin{array}{c}1590 \mathrm{~s} \\
1620 \mathrm{sh}\end{array}$ & - & 1295 & 720 & 490 & 476 \\
\hline $\mathrm{Ni}(\mathrm{SOP})(2-\mathrm{Mbtz})]$ & $1605 \mathrm{~s}$ & 3300 & 1310 & - & 480 & 460 \\
\hline$[\mathrm{Ni}(\mathrm{SOP})(\mathrm{Morph})]$ & $1610 \mathrm{~s}$ & - & 1300 & 700 & 490 & 465 \\
\hline$[\mathrm{Cu}(\mathrm{SOP})(\mathrm{Btz})]$ & $1650 \mathrm{sh}$ & & & & & \\
\hline$\left[\mathrm{Cu}(\mathrm{SOT})_{2}(\mathrm{Morph})_{2}\right]$ & $1610 \mathrm{~s}$ & 3190 & 1200 & - & 480 & 470 \\
\hline
\end{tabular}

$\mathrm{s}=$ sharp, $\mathrm{sh}=$ shoulder

Electronic spectra and magnetic measurements

The electronic spectral data of the ternary complexes in nujol mull are given in Table 4. The absorption spectra of the $[\mathrm{Cu}(\mathrm{OHAE})(2-\mathrm{Atz})]$, $[\mathrm{Cu}(\mathrm{OHAE})(\mathrm{Btz})], \quad[\mathrm{Cu}(\mathrm{OHAE})(3-$ Msbtz)], [Cu(OHAE)(Tbdz)]. $\mathrm{H}_{2} \mathrm{O}$, $[\mathrm{Cu}(\mathrm{SOP})(\mathrm{Btz})]$ and $\left[\mathrm{Cu}(\mathrm{SOT})_{2^{-}}\right.$ (Morph $)_{2}$ ] ternary complexes are characterized mainly by three absorption bands in region 15,040$38,460 \mathrm{~cm}^{-1}$. The broad absorption band in the range $15,040-16,580 \mathrm{~cm}^{-1}$ is attributed to a d-d transition. The band in the $21,230-25,520 \mathrm{~cm}^{-1}$ range is assigned to a charge transfer transition. ${ }^{21 \& 22}$. Furthermore, the absorption band in the range 28,330 -
$34,015 \mathrm{~cm}^{-1}$ is attributed to an intraligand transition.

The electronic spectra of [Ni(SOP)(2-Atz)], [Ni(SOP)(Btz)], [Ni(SOP)(2-Mbtz)] and [Ni(SOP)(Morph)] ternary complexes are recorded as nujol null. The $\mathrm{d}-\mathrm{d}$ transitions could not be observed in the spectra of these complexes due to charge transfer tailing from UV to visible region, which precluded the assignment of the structure around the $\mathrm{Ni}(\mathrm{II})$ ion. The complexes exhibited, however, a band in the range 21,230$25,520 \mathrm{~cm}^{-1}$, ascribed to a charge transfer transition. ${ }^{23}$ The intraligand transitions are associated with the bands appearing in the ranges 27,470 34,015 and $37,740-38,460 \mathrm{~cm}^{-1}$. 
Table 4: Electronic spectral data of the ternary complexes $\left(\mathrm{cm}^{-1}\right)$.

\begin{tabular}{||l|c|c||}
\hline \multicolumn{1}{|c|}{ Compound } & $v_{\max }\left(\mathrm{cm}^{-1}\right)$ & Band assignment \\
\hline $\mathrm{Cu}((\mathrm{OHAE})(2-\mathrm{Atz})]$ & 15,780 & d-d transition \\
& 23,100 & Charge transfer \\
& 28,330 & Intraligand transition \\
\hline$[\mathrm{Cu}(\mathrm{OHAE})(\mathrm{Btz})]$ & 16,000 & d-d transition \\
& 24,390 & Charge transfer \\
& 32,570 & Intraligand transition \\
\hline$[\mathrm{Cu}(\mathrm{OHAE})(3-\mathrm{Msbtz})]$ & 16,580 & d-d transition \\
& 24,330 & Charge transfer \\
& 28,330 & Intraligand transition \\
\hline$[\mathrm{Cu}(\mathrm{OHAE})(\mathrm{Tbdz})] \cdot \mathrm{H}_{2} \mathrm{O}$ & 15,040 & d-d transition \\
& 23,700 & Charge transfer \\
& 33,440 & Intraligand transition \\
\hline$[\mathrm{Ni}(\mathrm{SOP})(2-\mathrm{Atz})]$ & 23,750 & Charge transfer \\
& $(27,470),(37,590)$ & Intraligand transition \\
\hline$[\mathrm{Ni}(\mathrm{SOP})(\mathrm{Btz}]$ & 23,200 & Charge transfer \\
& $(32,470),(37,740)$ & Intraligand transition \\
\hline $\mathrm{Ni}(\mathrm{SOP})(2-\mathrm{Mbtz})]$ & 23,700 & Charge transfer \\
& $(33,330),(38,460)$ & Intraligand transition \\
\hline$[\mathrm{Ni}(\mathrm{SOP})(\mathrm{Morph})]$ & 24,940 & Charge transfer \\
& $(32,790),(37,740)$ & Intraligand transition \\
\hline$[\mathrm{Cu}(\mathrm{SOP})(\mathrm{Btz})]$ & 15,650 & d-d transition \\
& 21,230 & Charge transfer \\
& 33,560 & Intraligand transition \\
\hline$\left[\mathrm{Cu}(\mathrm{SOT})_{2}(\mathrm{Morph})_{2}\right]$ & 16,390 & d-d transition \\
& 25,520 & Charge transfer \\
& 34,015 & Intraligand transition \\
\hline \hline
\end{tabular}

The above data can be discussed as follows:

(i) For the copper complexes, the position of their $\mathrm{d}-\mathrm{d}$ band in the range $15,040-16,580 \mathrm{~cm}^{-1}$ is found to be similar to that of a d$\mathrm{d}$ band exhibited by analogous imidazole, benzothiazole and benzoxazole complexes. ${ }^{24 \& 25}$ This may indicate coordination of the azoles and morpholine in the prepared copper complexes through the nitrogen atoms. This is further supported from the above mentioned assignment of the IR band in the region 460$470 \mathrm{~cm}^{-1}$ as $\mathrm{v}(\mathrm{Cu}-\mathrm{N})$.

A further confirmation of this coordination site in these complexes comes from a study done by Y. Muto et $a l^{26}$ on a series of $\mathrm{Cu}(\mathrm{II})$ complexes having the general formula $\left[\mathrm{Cu}(\mathrm{Ac})_{2} \mathrm{~L}\right]$ (where $\mathrm{Ac}=$ acetate and $\mathrm{L}$ represents some azoles derivatives). It 
was reported that in this series the nitrogen atom of the ligand $\mathrm{L}$ is most probably the donor atom.

(ii) A similar coordination mode is expected for the azoles and morpholine in the $\mathrm{Ni}(\mathrm{II})$ complexes (vNi-N,460-470 $\mathrm{cm}^{-1}$, Table 3). Aly et al..$^{10}$ prepared a number of $\mathrm{Ni}(\mathrm{II})$ mixed ligand complexes of alkylxanthate with benzothiazole, benzoxazole and morpholine in which these azoles and morpholine coordinate via the nitrogen atom.

Recently a mixed ligand complex of $\quad \mathrm{Co}(\mathrm{III})-\mathrm{N}, \mathrm{N}^{\prime}$-disalicylidene-1,2phenylenediamine dianion and morpholine was prepared where the latter coordinates through its nitrogen atom. Crystal structure determination confirmed this type of bonding. ${ }^{27}$

The effective magnetic moment values for the invetigated $\mathrm{Ni}$ (II) complexes are in the range 3.4-3.6 B.M., which may indicate their tetrahedral structure. These values are lower than expected value (4.1 B.M.), probably due to the effect of covalency or distortion from the tetrahedral structure. $^{28}$ The $\mathrm{Cu}(\mathrm{II})$ complexes display, however, effective magnetic moment values in the range 1.62-1.79 B.M. It is asumed that the copper complexes adopt a tetragonal geometry which is produced probably through the interaction of the copper in the complexes with adjacent ligands of neighboring complex molecules.

\section{$\mathrm{X}$-ray powder diffraction}

The compounds [Cu(OHAE)(Tbdz)]. $\mathrm{H}_{2} \mathrm{O}, \quad[\mathrm{Ni}(\mathrm{SOP})(2-\mathrm{Atz})]$ $[\mathrm{Ni}(\mathrm{SOP})(\mathrm{Btz})],[\mathrm{Cu}(\mathrm{SOP})(\mathrm{Btz})]$ and $\left[\mathrm{Cu}(\mathrm{SOT})_{2}(\mathrm{Morph})_{2}\right]$ were studied by $\mathrm{X}$-ray powder diffraction. In Table 5, the (d) spacing, (20) and the relative intensities of the lines in the powder diffraction pattern of [Cu(OHAE)(Tbdz)]. $\mathrm{H}_{2} \mathrm{O}$ are tabulated. The patterns of the complexes display lines indicating that the complexes are more or less crystalline.

\section{Tenative structures}

Although it was difficult to assign the structures of the complexes from the electronic spectral data due to the great broadness of the d-d transition band in the copper complexes and the absence of this band in the nickel complexes, the magnetic moment data indicate the tetrahedral structure of the $\mathrm{Ni}(\mathrm{II})$ complexes and the tetragonal structure of the $\mathrm{Cu}(\mathrm{II})$ complexes. In the following are the tentative structures of the complexes: 
Table 5: X-ray powder diffraction data for $[\mathrm{Cu}(\mathrm{OHAE})(\mathrm{Tbdz})] \cdot \mathrm{H}_{2} \mathrm{O}$.

\begin{tabular}{||c|c|c||c|c|c||}
\hline \hline$(2 \theta)$ & $\begin{array}{c}(\mathrm{d}) \\
\text { spacing }\end{array}$ & $\begin{array}{c}\text { Relative } \\
\text { intensity }\left(\mathrm{I} / \mathrm{I}_{\mathrm{o}}\right)\end{array}$ & $(2 \theta)$ & $\begin{array}{c}(\mathrm{d}) \\
\text { spacing }\end{array}$ & $\begin{array}{c}\text { Relative } \\
\text { intensity }\left(\mathrm{I} / \mathrm{I}_{\mathrm{O}}\right)\end{array}$ \\
\hline 10.52 & 8.409 & 15 & 37.85 & 2.377 & 37 \\
\hline 11.08 & 7.986 & 17 & 38.68 & 2.328 & 23 \\
\hline 12.70 & 6.969 & 28 & 39.88 & 2.26 & 21 \\
\hline 14.84 & 5.969 & 16 & 43.08 & 2.1 & 22 \\
\hline 16.54 & 5.36 & 52 & 44.48 & 2.037 & 27 \\
\hline 17.55 & 5.054 & 46 & 45.32 & 2.001 & 18 \\
\hline 18.24 & 4.863 & 23 & 45.52 & 1.993 & 19 \\
\hline 21.03 & 4.224 & 100 & 46.00 & 1.973 & 20 \\
\hline 22.01 & 4.039 & 19 & 48.44 & 1.879 & 19 \\
\hline 22.64 & 3.927 & 14 & 49.0 & 1.858 & 21 \\
\hline 23.91 & 3.721 & 27 & 50.32 & 1.813 & 19 \\
\hline 24.89 & 3.578 & 38 & 51.52 & 1.774 & 20 \\
\hline 25.52 & 3.49 & 29 & 52.56 & 1.74 & 18 \\
\hline 26.31 & 3.387 & 59 & 55.36 & 1.717 & 19 \\
\hline 27.25 & 3.273 & 24 & 54.16 & 1.693 & 20 \\
\hline 27.72 & 3.218 & 19 & 54.56 & 1.682 & 18 \\
\hline 28.76 & 3.104 & 19 & 54.68 & 1.679 & 19 \\
\hline 29.44 & 3.034 & 16 & 56.24 & 1.636 & 19 \\
\hline 31.84 & 2.81 & 29 & 56.64 & 1.625 & 19 \\
\hline 32.40 & 2.763 & 19 & 60.44 & 1.532 & 19 \\
\hline 33.28 & 2.692 & 23 & 61.76 & 1.502 & 17 \\
\hline 34.24 & 2.619 & 18 & 62.36 & 1.489 & 19 \\
\hline 35.56 & 2.525 & 23 & 62.99 & 1.476 & 22 \\
\hline 37.04 & 2.427 & 20 & 65.08 & 1.433 & 18 \\
\hline \hline
\end{tabular}




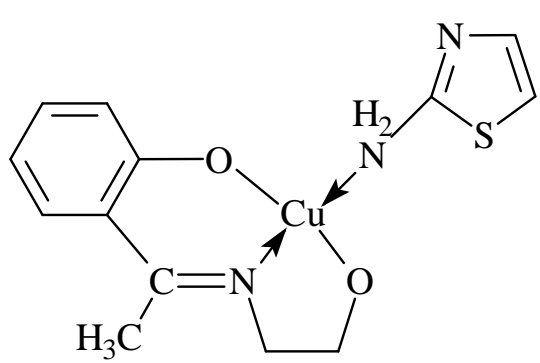

$\mathrm{Cu}((\mathrm{OHAE})(2-\mathrm{Atz})]$

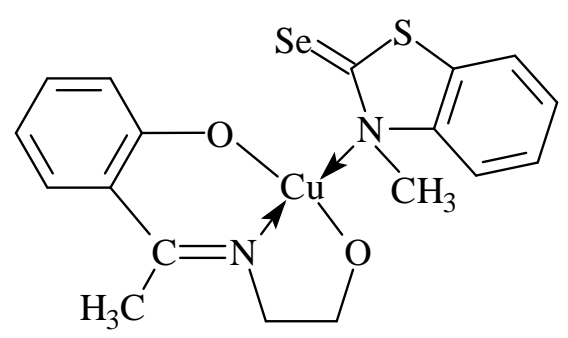

[Cu(OHAE)(3-Msbtz)]

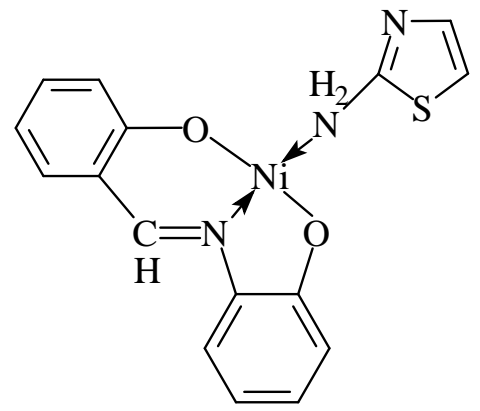

[Ni(SOP)(2-Atz)]

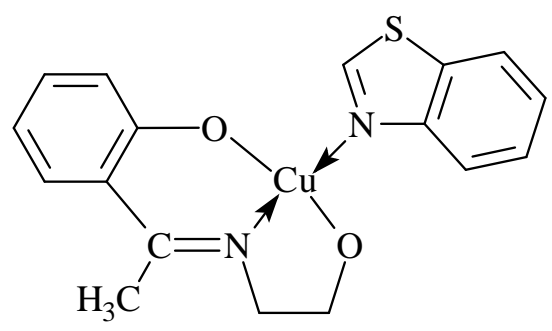

[Cu(OHAE)(Btz)]

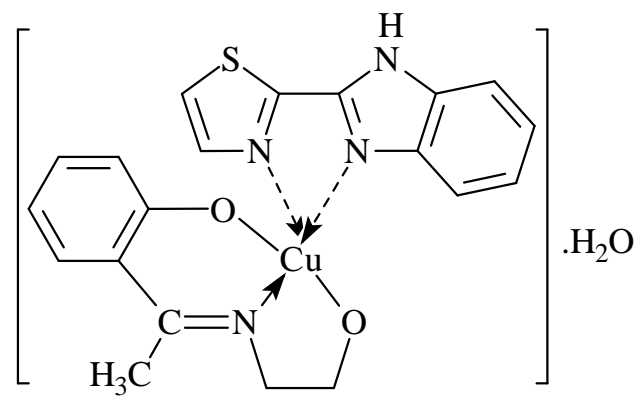

$[\mathrm{Cu}(\mathrm{OHAE})(\mathrm{Tbdz})] \cdot \mathrm{H}_{2} \mathrm{O}$

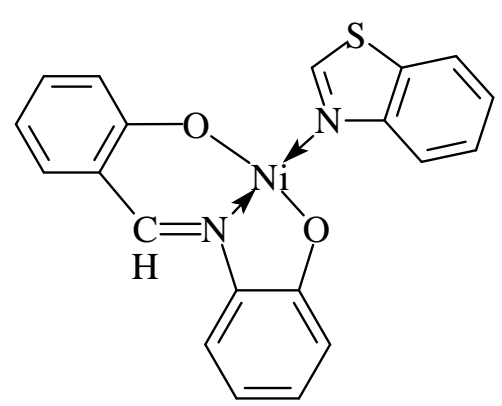

[Ni(SOP)(Btz] 


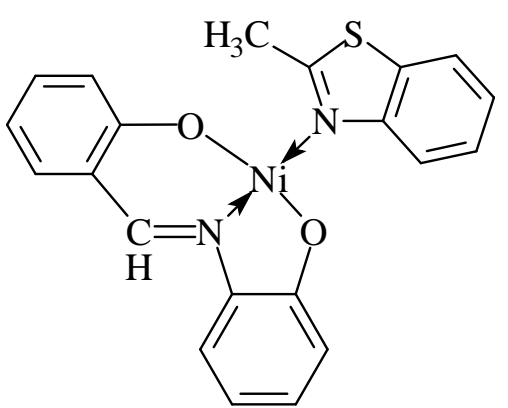

$\mathrm{Ni}(\mathrm{SOP})(2-\mathrm{Mbtz})]$

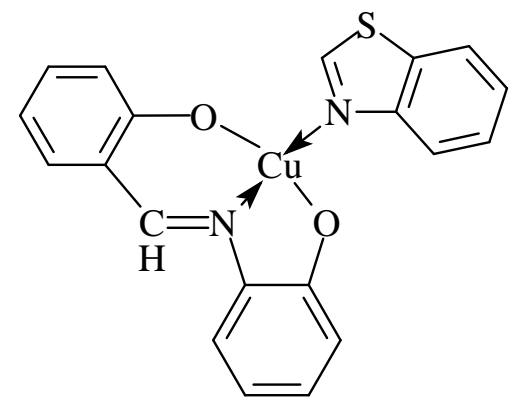

$[\mathrm{Cu}(\mathrm{SOP})(\mathrm{Btz})]$

\section{Acknowledgment}

One of the authors (A. A. M. Aly) is grateful to the Alexander von Humboldt - Foundation for donating the magnetic susceptibility balance (MSB-Auto).

\section{REFERENCES}

1- S. M. El-Kousy, F. A. Ali, A. M. Donia and F. A. El-Said, Egypt. J. Pharm. Soc., 28, 107 (1987).

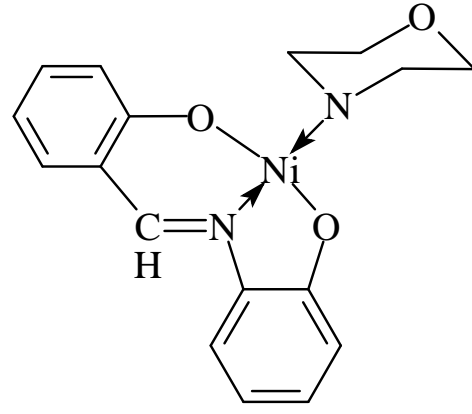

[Ni(SOP)(Morph)]

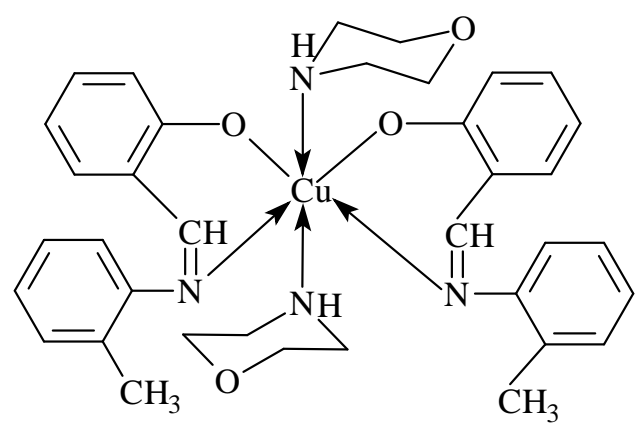

$\left[\mathrm{Cu}(\mathrm{SOT})_{2}(\mathrm{Morph})_{2}\right]$

2- C. P. Raptopoulou, A. N. Papadopoulou, D. A. Malamatari, E. Loannidis, G. Molsidis, A. Terzis and D. P. Kessissoglou, Inorg. Chim. Acta, 272, 283 (1998).

3- R. Pignatello, A. Panicol, P. Mazzone, M. Pinizzotto, A. Garozzo and P. Furneri, Eur. J. Med. Chem., 29, 781 (1994).

4- L. Guofa, S. Tongshum and Z. Yonghian, J. Mol. Struct., 412, 75 (1997). 
5- F. Bergant, S. Pacar, S. Ghosh, S. K. Chattopadhyay and G. Sava, Anti Cancer Res., 13, 1007 (1993).

6- L. S. Goodman and A. Gilman, "The Pharmacological Basis of Therapeutics", $5^{\text {th }}$ Ed., Macmillan, New York (1975).

7- R. lackhan and B. Ternai, Adv. Heterocy. Chem., 17, 99 (1974).

8- B. K. Keppler, "Metal Complexes in Cancer Themotherapy", $\mathrm{VCH}$, Weinheim (1993).

9- P. Mura, F. Piccioli, C. Gabbianai, M. Camalli and L. Messori, Inorg. Chem., 44, 4897 (2005).

10- A. A. M. Aly, M. S. El-Meligy, A. S. A. Zidan and M. ElShabasy, Synth. React. Inorg. Met.-Org. Chem., 17, 257 (1987).

11- A. A. M. Aly, M. S. El-Meligy, A. S. Zidan and M. El-Shabasy, An. Quim., 86, 19 (1990).

12- A. H. Osman, A. A. M. Aly, M. Abd El-Mottaleb and G. A. H. Gouda, Bull. Korean Chem. Soc., 25, 45 (2004).

13- P. R. Shukla, V. K. Singh and A. M. Jaiswal, J. Indian Chem. Soc., LX, 321 (1983).

14- A. P. Mishra, M. Khare and S. K. Gautam, Synth. React. Inorg. Met.-Org. Chem., 32, 1485 (2002).

15- A. M. Shallaby, M. M. Mostafa and M. M. Bekheit, Indian J. Chem., 17A, 516 (1979).
16- B. A. Jani and P. K. Bhattacharya, J. Indian Chem. Soc., LVIII, 207 (1981).

17- a) H. M. El-Tabl, F. A. El-Saied and M. I. Ayad, Synth. React. Inorg. Met.-Org. Chem., 32, 1245 (2002). b) A. A. AbouHussen, N. M. El-Metwally, E. M. Saad and A. A. El-Asmy, J. Coord. Chem., 58, 1735 (2005).

18- M. X. West, H. Gebremedhin, T. J. Romack and A. E. Liberta, Transition Met. Chem., 19, 426 (1994).

19- S. I. Valentina and P. A. Mikhail, Inorg. Chim. Acta, 189, 259 (1991).

20- a) N. T. Madhu and P. K. Radhakrishnan, Transition Met Chem., 25, 287 (2000). b) N. M El-Metwally, I. M. Gabr, A. A El-Asmy and A. A. AbouHussen, Transition Met. Chem., 31, 71 (2006).

21- S. Kumar and N. K. Kaushik, Inorg. Nucl. Chem., 11, 43 (1981).

22- S. Wang and S. Liu, Inorg. Chem. Acta, 196, 231 (1992).

23- a) A. I. El-Said, A. S. A. Zidan, M. S. El-Meligy, A. A. M. Aly and O. F. Mohammed, Synth. React. Inorg. Met.-Org. Chem., 30, 1373 (2000). b) A. A. A. Abu-Hussein, J. Coord. Chem., 59, 157 (2006).

24- S. V. Deshpande and T. S Srivastava, Polyhedron, 2, 261 (1983). 
25- A. A. Mohamed, A. A. M. Aly and M. El-Shabasy, Croat. Chim. Acta, 59, 509 (1986).

26- Y. Muto, T. Tokii, K. Chijiwa and M. Kato, Bull. Chem. Soc. Japn., 57, 1011 (1984).
27- M. Amirnasr, K. J. Schenk, A. Gorji and R. Vafazadeh, Polyhedron, 20, 695 (2001).

28- L. Sacconi, R. Cini, M. Ciampalini and F. Maggo, J. Am. Chem. Soc., 82, 3487 (1960). 